\title{
DÜBLIN
}

Technological University Dublin

ARROW@TU Dublin

Conference Papers

School of Manufacturing and Design

Engineering

2006-01-01

\section{A Numerical Acoustic Fluid-structure Model of a Therapeutic Ultrasound Angioplasty Device}

\author{
Graham Gavin \\ Technological University Dublin, graham.gavin@tudublin.ie \\ M.S. J. Hashmi \\ Dublin City University \\ Finbar Dolan \\ Medtronic Vascular Ltd, Galway
}

See next page for additional authors

Follow this and additional works at: https://arrow.tudublin.ie/engschmanconn

Part of the Biomedical Engineering and Bioengineering Commons, and the Manufacturing Commons

\section{Recommended Citation}

Gavin, G., Hashmi, M., Dolan, F., McGuinness, G.: A numerical acoustic fluid-structure model of a therapeutic ultrasound angioplasty device. Journal of Biomechanics, Volume 39, Supplement 1, 2006, Page S309, Abstracts of the 5th World Congress of Biomechanics. doi: 10.21427/ttn4-2m20

This Conference Paper is brought to you for free and open access by the School of Manufacturing and Design Engineering at ARROW@TU Dublin. It has been accepted for inclusion in Conference Papers by an authorized administrator of ARROW@TU Dublin. For more information, please contact arrow.admin@tudublin.ie, aisling.coyne@tudublin.ie,gerard.connolly@tudublin.ie.

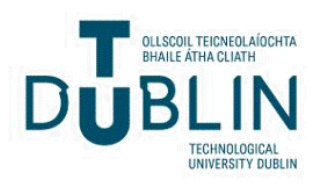




\section{Authors}

Graham Gavin, M.S. J. Hashmi, Finbar Dolan, and Garrett McGuinness

This conference paper is available at ARROW@TU Dublin: https://arrow.tudublin.ie/engschmanconn/3 
A numerical acoustic fluid-structure model of a therapeutic ultrasound angioplasty device

Graham P. Gavin ${ }^{\mathrm{a}}$, Saleem Hashmi ${ }^{\mathrm{a}}$, Finbar Dolan ${ }^{\mathrm{b}}$ and Garrett B. McGuinness ${ }^{\mathrm{a}}$

${ }^{a}$ School of Mechanical and Manufacturing Engineering, Dublin City University, Ireland

${ }^{\mathrm{b}}$ Medtronic Vascular, Galway, Ireland

Ultrasonic angioplasty involves the use of ultrasonic vibrations delivered to the distal-tip of small diameter wire waveguides and is an emerging technology the may have potential use in the treatment of complicated atherosclerotic plaques during cardiovascular surgery. Complicated plaques, including chronic total occlusions and calcified lesions, seriously reduce success rates during standard intervention involving guidewire access, followed by balloon dilation or stent delivery. The large amplitude $(0-150 \mu \mathrm{m})$ wire waveguide distal-tip displacements in the low-frequency ultrasonic $(18-45 \mathrm{kHz})$ range have been shown to disrupt plaque material by direct contact ablation and cavitation, acoustic streaming and pressure wave components in adjacent fluid ${ }^{1}$. The effects on this surrounding fluid are complex and are related to the distal-tip geometry, frequency of operation, vibration amplitude, as well as the operating environment, including, fluid properties and boundary conditions. While the majority of work to date on ultrasound angioplasty has focused on experimental and clinical studies ${ }^{2,3}$, further understanding of distal-tip effects is necessary. This work describes a numerical fluid-structure model of the wire waveguide distal-tip and is used to predict the pressures developed in the fluid region near the tip wall, the acoustic pressure field and, with the inclusion of appropriate threshold intensity, when cavitation will occur. The model has been validated against experimental acoustic pressure field results reported in the literature. The model can be further used to predict the effects of parameters such as distal-tip geometry, displacement amplitude and frequency of operation and will prove a valuable design aid in the choice of optimum powers to disrupt various biological materials.

1. Atar S et al. Ultrasonic Thrombolysis: catheter-delivered and transcutaneous applications. European Journal of Ultrasound, 1999.

2. Makin RS and Everbach EC, J. Acoust. Soc. Am., 1996.

3. Ultrasound Angioplasty. Developments in Cardiovascular Medicine. (Ed. by Siegel RJ). Kluwer Academic Publishers, 1996. 